\title{
Spray Volume, Distribution, and Efficacy of 5-Chloro-3-methyl-4- nitro-1H-pyrazole for Loosening Sweet Orange
}

\author{
Robert C. Ebel ${ }^{1,4}$ \\ University of Florida, IFAS, Southwest Florida Research and Education \\ Center, 2686 Highway 29 N., Imokalee, FL 34142
}

Jacqueline K. Burns ${ }^{2}$

Citrus Research and Education Center, 700 Experiment Station Road, Lake

Alfred, FL 33850

\author{
Kelly T. Morgan ${ }^{3}$ \\ University of Florida, IFAS, Southwest Florida Research and Education \\ Center, 2686 Highway 29 N., Immokalee, FL 34142
}

Additional index words. 5-chloro-3-methyl-4-nitro-1H-pyrazole, water-sensitive paper, 'Valencia', 'Hamlin', mechanical harvest, vertical multi-fan air-blast sprayer, citrus

Abstract. The abscission compound CMNP (5-chloro-3-methyl-4-nitro-1H-pyrazole) was applied to fully mature sweet orange trees at different spray volumes using a vertical, multiple-fan air-blast sprayer to determine distribution of fruit loosening throughout the canopy and subsequent effects on mechanical harvester efficiency. CMNP was applied at

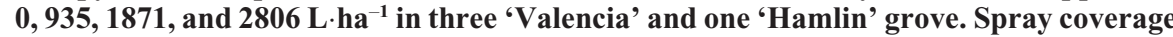
was measured using water-sensitive paper and fruit loosening was measured by fruit detachment force (FDF). Spray coverage and FDF were measured at 1-, 2-, and 4-m height within the canopy and inside the canopy near the trunk and on the periphery of the canopy. Spray coverage increased with volume of CMNP applied. Spray coverage was higher at $4 \mathrm{~m}$ than 1 and $2 \mathrm{~m}$, which were similar. Spray coverage within the canopy was decreased almost half compared with that of the periphery. FDF was unaffected by spray volume at the different heights except in one trial where fruit had higher FDF at $4 \mathrm{~m}$. Fruit inside the canopy did not loosen as much as fruit outside the canopy in three of the four trials. FDF inside the canopy averaged 52 to $84 \mathrm{~N}$, whereas fruit on the periphery of the canopy averaged 50 to $74 \mathrm{~N}$. CMNP promoted fruit drop, but only in two trials was the amount over $5 \%$ of the total yield for the $2806-\mathrm{L} \cdot \mathrm{ha}^{-1}$ treatment. The fruit were harvested by canopy shakers that captured fruit on catch frames, except one of the 'Valencia' trials in which the canopy shaker did not have a catch frame. The percent of the total crop removed by the harvesters increased when CMNP was applied at higher spray volumes except in the 'Hamlin' trial in which there was no difference among volume treatments. The percent of the total crop removed by the harvester but not captured by the catch frame increased at higher volumes of CMNP applied for two of the three trials in which catch frames were used. Fruit loss with greater volume of CMNP applied was promoted by peripheral canopy contact with the front shield of the harvester that knocked fruit down before the catch frame moved under that portion of the canopy. Recovery percentage, or the percentage of total yield that was caught and conveyed to bulk collection by the harvester catch frame, averaged $78.1 \%$ to $87.8 \%$ of total yield. Higher CMNP volume with increased removal rate compensated for higher catch frame loss, providing overall higher recovery percentage. Based on the goals of minimizing fruit drop and maximizing fruit recovery, the range of FDF that should be reached by harvest is $40 \mathrm{~N}$ to $65 \mathrm{~N}$ for canopy shakers equipped with catch frames. These trials underscore the importance of adequate CMNP coverage for reducing in-canopy variation of fruit loosening and maximizing fruit removal.

The citrus industry in Florida has 193,000 ha of sweet oranges [Citrus sinensis (L.) Osbeck] grown principally for the fresh juice industry (Anonymous, 2008) of which $\approx 13,153$ ha are mechanically harvested (Florida Department of Citrus, 2008). Removal rates without abscission-promoting compounds have ranged from $50 \%$ to $98 \%$ in research studies (Whitney, 1975, 2000, 2003; Whitney et al., 2000a, 2000b; Whitney et al., 2001). The limitations of mechanical harvesters are especially acute for late-season 'Valencia', in which harvesting of the mature crop overlaps temporally with development of the new crop. 'Valencia' trees typically bloom in late February through March in Florida, and by early May, the immature fruit are large enough to be removed by mechanical harvesters, thus potentially reducing yield the next year. To preserve long-term productivity, most commercial mechanical harvesting in Florida currently ends in early May. Abscission compounds that increase removal rates by mechanical harvesters, and especially increase removal of mature lateseason 'Valencia' fruit without removing the newly developing crop, have received considerable research attention in recent years.

Studies have been conducted to identify compounds that promote hydrolytic digestion of the abscission layer of mature sweet oranges. Of the compounds tested, 5-chloro3-methyl-4-nitro-1H-pyrazole (CMNP) has been shown to be the most effective (Burns et al., 2005; Freeman and Sarooshi, 1976; Koo et al., 1999; Whitney, 1975, 1976; Whitney et al., 2000a, 2000b; Wilson, 1973) and as a result, CMNP is currently being intensely studied as an aid to commercial mechanical harvesting, especially for late-season 'Valencia' because it does not promote abscission of the newly developing fruit (Burns et al., 2006). Efficacy of CMNP in promoting sweet orange fruit abscission is affected by several variables, especially concentration and coverage, temperature, and postspray precipitation events (Ebel and Burns, 2008). Furthermore, direct peel contact of CMNP is essential for promoting abscission of sweet oranges (Alferez et al., 2005). The effect of these variables on CMNP efficacy will need to be determined to optimize CMNP application and mechanical harvesting scheduling in commercial sweet orange groves.

Because CMNP requires direct peel contact to promote fruit abscission, uniform spray coverage throughout the canopy will be required. Air-blast sprayers have been the most widely used method of pesticide and plant growth regulator applications in commercial citrus groves in Florida. Air-blast sprayers project spray droplets upward, and although there is some turbulence outside and within the canopy, coverage is not as uniform as multihead tower sprayers that provide spray at all levels of the canopy (BenSalem et al., 2001; Farooq et al., 2003; Koo et al., 1999, 2000; Salyani et al., 2002). The advantages of vertical, multi-fan sprayers compared with air-blast sprayers in improving spray coverage has also been shown for an abscission agent for sweet oranges (Burns et al., 2006). Optimal sprayer design for CMNP application will need to include sufficient penetration into the canopy, especially considering that detachment force of fruit inside the canopy is naturally higher than fruit on the periphery (Kender and Hartmond, 1999). Optimum sprayer design will also need to include thorough coverage of fruit near the top of the canopy, because this fruit tends to have higher detachment force than fruit lower in the canopy (Kender and Hartmond, 1999).

This study was conducted using a sprayer that has the desirable features of providing spray throughout the canopy. The sprayer has multiple fans that deliver spray from the lowest branches and arching over the top of the canopy (Fig. 1). Using this sprayer 


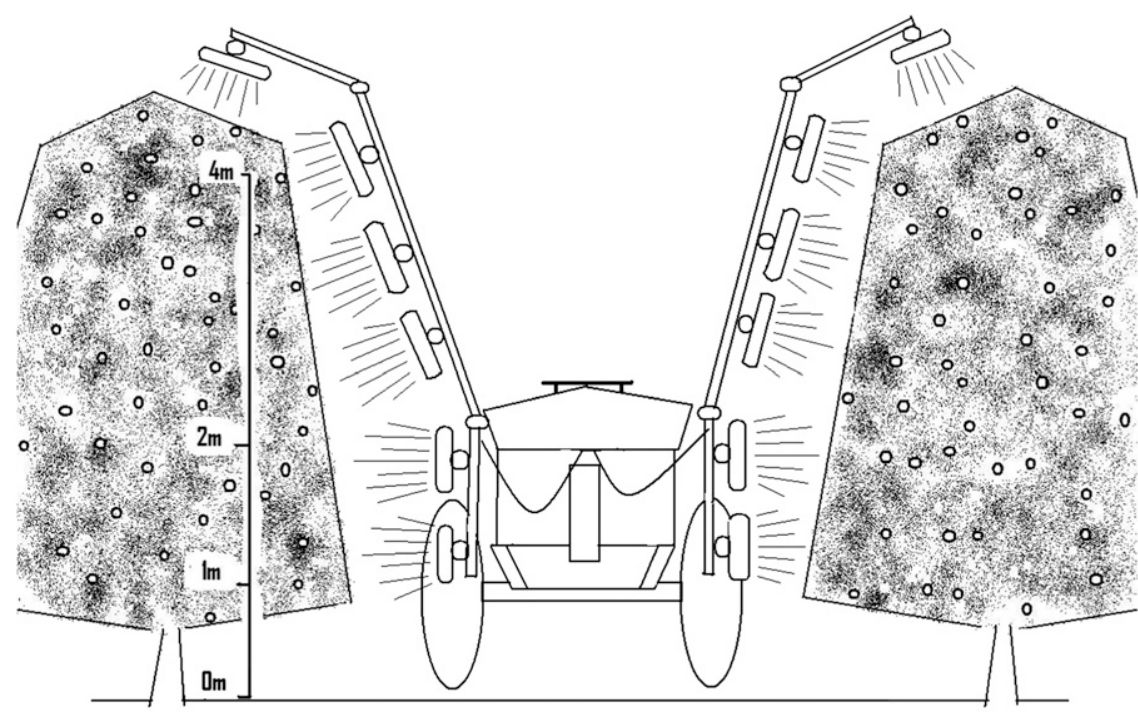

Fig. 1. Diagram of the vertical, multiple-fan air-blast sprayer used in this study. Note that the upper fan is offset such that the upper portion of the canopy receives a higher volume of spray.

technology, the objective of this study was to determine the relationship of CMNP spray volume applied per hectare to the distribution of spray and fruit loosening in the canopy and percent crop removed by mechanical harvesters. The relationships were determined under the most challenging grove conditions by using fully mature trees with full canopies.

\section{Materials and Methods}

\section{6 trials}

Plant material and culture. Two trials were conducted near Immokalee, FL, in commercial groves that used standard cultural practices. The first trial was conducted on 17-year-old, 'Hamlin' orange trees [Citrus sinensis (L.) Osbeck] on Swingle citrumelo (Citrus paradisi $\times$ Poncirus trifoliata) rootstock at a commercial grove (Barron Collier, Silverstrand North, block C-13). Trees were spaced $3.6 \mathrm{~m} \times 7.3 \mathrm{~m}(350$ trees/ha) and the canopy averaged $4.4 \mathrm{~m}$ in height and $4.2 \mathrm{~m}$ in diameter. Lower limbs of the canopy were pruned to $1.1 \mathrm{~m}$ above the soil line (skirted). The second trial was conducted on 20-year-old 'Valencia' orange trees on Swingle rootstock at a commercial grove (Barron Collier, Silverstrand III, block

\footnotetext{
Received for publication 11 Feb. 2009. Accepted for publication 21 Sept. 2009.

This project was funded by UF/IFAS Citrus Initiative Funds.

We thank Peter Newman and Luis Pozo for their technical assistance. We also express our appreciation to OXBO International Corp. for use and technical assistance with the multiple-fan sprayers. We also thank AgroSource ${ }^{\mathrm{TM}}$ Inc., Florida Department of Citrus, and Drs. Fritz Roka and Bob Rouse for their review of the manuscript.

${ }^{1}$ Associate Professor.

${ }^{2}$ Professor.

${ }^{3}$ Assistant Professor

${ }^{4}$ To whom reprint requests should be addressed; e-mail rcebel@ufl.edu.
}

by total yield of each tree to determine a percent of preharvest fruit drop. Trees were mechanically harvested using a trunk shaker equipped with a catch frame (Coe-Collier Citrus Harvesting, LLP, Immokalee, FL). Each tree was shaken for $5 \mathrm{~s}$ at $\approx 8 \mathrm{~Hz}$. Fruit mechanically harvested and caught on the catch frame were collected, weighed, and divided by total yield to determine percent removal. Fruit on the ground that had missed the catch frame during machine harvesting were collected, weighed, and divided by total yield to determine the percent catch frame loss. Fruit remaining in the canopy after shaking were removed by hand, weighed, and divided by total yield to determine percent gleaned.

Total yield was determined by adding the weights of the preharvest drop fruit, the fruit caught by the catch frame, the fruit that missed the catch frame, and the fruit gleaned.

Experimental design. Both trials were set up as randomized complete block designs with four blocks and three adjacent trees per plot. There was a buffer row between treatment rows and at least two buffer trees between plots. The data from the three trees were collected and the average per tree estimated before analysis.

\section{8 trials}

Plant material and culture. Two trials

Treatments. Trees were sprayed with a multihead air-blast sprayer ("GreenTech," Model 4000L; OXBO International, Clear Lake, WI) with two vertical $5.5-\mathrm{m}$ booms oriented parallel to and arched over the outer part of the canopy in opposing directions. Each boom had six equally spaced fan/nozzle assemblies. Each fan assembly contained eight Conejet \#12 nozzles (Spraying Systems Col., Wheaton, IL) operating at 16.2 Mpa $\mathrm{cm}^{-2}$. CMNP (17\% a.i.) was applied at $200 \mathrm{mg} \cdot \mathrm{L}^{-1}$ with Kinetic adjuvant (Helena Chemical Co., Memphis, TN) with different volumes per hectare as treatments. The 'Hamlin' orange trees were sprayed on 9 Jan. 2006 with 1873 and $2810 \mathrm{~L} \cdot \mathrm{ha}^{-1}$ and the 'Valencia' trees were sprayed on 27 Mar. 2006 with 935, 1871, and $2806 \mathrm{~L} \cdot \mathrm{ha}^{-1}$. The water volume treatments were achieved by varying ground speed of the tractor at 5.6, 2.5 , and $1.6 \mathrm{~km} \cdot \mathrm{h}^{-1}$, respectively. Each trial had an unsprayed control.

Data collected. Fruit detachment force (FDF) was determined $4 \mathrm{~d}$ after CMNP application from 10 randomly selected fruit per canopy position. There were six canopy positions sampled, which varied by height and depth within the canopy. Fruit were sampled at 1-, 2-, and 4-m heights and inner $(0.3 \mathrm{~m}$ from the trunk) and outer $(0.3 \mathrm{~m}$ from the canopy edge) the canopy. FDF was measured using a force gauge (Force One digital force gauge; Wagner Instruments, Greenwich, CT) as described previously (Pozo et al., 2004).

Immediately before harvesting with the mechanical harvester, fruit beneath each tree were counted and the total weight estimated by using the average weight of 10 fruit. Preharvest dropped fruit weight was divided FL, and the second near Immokalee, FL, in commercial groves that used standard cultural practices.

The first trial was conducted on 20-yearold 'Valencia' orange trees on Swingle rootstock (Lykes Brothers, Lake Wales, Camp Mack grove). The trees were spaced $3.0 \mathrm{~m} \times$ $6.5 \mathrm{~m} \mathrm{(500} \mathrm{trees/ha)} \mathrm{and} \mathrm{the} \mathrm{canopy} \mathrm{averaged}$ $4.2 \mathrm{~m}$ in height and $3.8 \mathrm{~m}$ in diameter. The canopy was skirted to $0.8 \mathrm{~m}$ above the soil line. The second trial was conducted on 20year-old 'Valencia' orange trees on Carrizo citrange $[C$. sinensis $\times$ Poncirus trifoliata (L.) Raf.] rootstock at a commercial grove (Barron Collier, Oak Hammock Grove block A-1). The trees were spaced $3.0 \mathrm{~m} \times 6.1 \mathrm{~m}$ ( 542 trees/ha) and the canopy averaged $4.0 \mathrm{~m}$ in height and $3.1 \mathrm{~m}$ in diameter with the dimension maintained by annual hedging. The canopy was skirted to $1.2 \mathrm{~m}$ above the soil line.

Treatments. Trees in both trials were sprayed with a vertical, multihead sprayer (Model T1000; OXBO International). The sprayer design was identical to that of the "GreenTech" sprayer described previously. Each fan had HCX \#12 nozzles (Spraying Systems Col.) operating at 165 psi. CMNP (17\% a.i.) was applied at $250 \mathrm{mg} \cdot \mathrm{L}^{-1}$ in the first trial and $300 \mathrm{mg} \cdot \mathrm{L}^{-1}$ in the second trial. Both trials used Activator 90 as an adjuvant (Alkylphenol ethoxylate, alcohol ethoxylate, and tall oil fatty acid; Loveland Products, Inc. Greeley, CO). Both trials were sprayed with 935,1871 , and $2806 \mathrm{~L} \cdot \mathrm{ha}^{-1}$. The first trial was sprayed at $1015 \mathrm{HR}$ on $10 \mathrm{Apr}$. and the second trial was sprayed at $1130 \mathrm{HR}$ on 17 Apr. 2008. The 935-, 1873-, and 2810-L·ha ${ }^{-1}$ treatments were conducted, the first near Lake Wales, 
were achieved by varying ground speed of the tractor and pressure of the sprayer at 8.1 $\mathrm{km} \cdot \mathrm{h}^{-1}$ and $7.0 \mathrm{~kg} \cdot \mathrm{cm}^{-2}, 4.3 \mathrm{~km} \cdot \mathrm{h}^{-1}$ and 8.8 $\mathrm{kg} \cdot \mathrm{cm}^{-2}$, and $2.9 \mathrm{~km} \cdot \mathrm{h}^{-1}$ and $8.8 \mathrm{~kg} \cdot \mathrm{cm}^{-2}$, respectively. Each trial had an unsprayed control.

Data collected. For both trials, FDF was determined $4 \mathrm{~d}$ after CMNP application from five randomly selected fruit per canopy position as described previously. Fruit beneath each plot were collected and weighed before mechanical harvest and preharvest drop determined as described in the 2006 procedure. In the first trial, trees were mechanically harvested using a pull-behind canopy shaker without a catch frame (Model 3210; OXBO International). Fruit on the ground were collected and weighed. Preharvest fruit drop, removal, and glean percentage were calculated as described in the 2006 procedure. In the second trial, fruit were mechanically harvested by two self-propelled canopy shakers (Model 3220; OXBO International) working on either side of each tree in tandem at $2.4 \mathrm{~km} \cdot \mathrm{h}^{-1}$ with the canopy shakers operating at $3.7 \mathrm{~Hz}$. Preharvest drop, removal, catch frame loss, recovery, and gleaning percentage were calculated as described in the 2006 procedure.

Total yield was determined using the same method as the 2006 trials.

Spray deposition. In the second trial, and before application of CMNP, water-sensitive paper (product number 20301-2N; Rittenhouse Co., Ontario, Canada) was placed in the canopy at six positions, at 1-, 2-, and 4-m heights and inside ( $0.3 \mathrm{~m}$ from the trunk) and outside ( $0.3 \mathrm{~m}$ from the canopy edge). After spray, the cards were removed from the trees and pooled by plot and a digital image taken using a digital camera (Model S8100FD; Fujifilm Holdings Corp., Tokyo, Japan). The Hunter " $b$ " color value, which measures the relative yellow to blue ratio (McGuire, 1992; Voss and Robinson, 1992), was determined from two randomly selected $60 \times$ 500-pixel areas of the treatment cards. Cards removed from control trees were measured, and the mean " $b$ " value was determined and used to represent $0 \%$ coverage using digital analysis software (ImageJ 1.41; Wayne Rasband, National Institutes of Health, Bethesda, MD). The "b" values of five cards completely wetted by the spray treatment and thus showing the highest level of blue color were determined similarly and the mean value used to represent $100 \%$ coverage. The average " $b$ " value for each card was determined and the percent coverage was calculated.

Experimental design. Both trials were set up as randomized complete block designs with four blocks. The first trial had three adjacent trees per plot and the second trial had eight trees per plot. There was a buffer row between treatment rows and at least two buffer trees between plots. The data from all trees per plot were collected and the average per tree estimated before analysis.

Statistical analysis. Water-sensitive paper and FDF data were analyzed by finding the mean at each location within the canopy, and testing location effects by including in the model the height by depth interaction and the height and depth main effects, and using the residual sums of squares to test their significance. Yield data were analyzed as randomized complete block designs by using the means from the three-tree replicates as the experimental units. These data were analyzed using the General Linear Models procedures of the Statistical Analysis System (SAS Institute, Inc., Cary, NC). Linear regressions for CMNP applied in the Immokalee 2008 study were developed with spray card coverage and FDF using the regression software of Sigmaplot (Sigmaplot 11.0; Systat Software, Inc., San Jose, CA).

\section{Results and Discussion}

Distribution of spray and fruit loosening within the canopy. Analysis of color change on wetted paper allowed for estimates of penetration by spray volume. There was no significant height by depth interaction with the percent of wetted paper that was contacted by spray droplets; however, there were significant depth $(P=0.0030)$ and height $(P<$ $0.0001)$ effects on spray coverage (Table 1$)$. As expected, there was less coverage inside $(25 \%)$ than on the periphery $(40 \%)$ of the canopy. There was also better coverage at the 4-m height in the canopy (51\%) than at the $1 \mathrm{~m}$

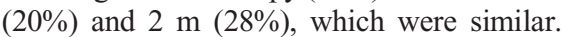
Better spray coverage at the 4-m height is the result of the structure of the sprayer, which has the upper fan at a more horizontal angle than the lower five fans, which are more vertically oriented (Fig. 1). Thus, the upper two fans provide greater overlap in spray coverage.

Table 1. Distribution of spray using water-sensitive paper and fruit detachment force within the canopy of 'Valencia' trees in three trials and 'Hamlin' trees in one trial that were sprayed with CMNP at different volumes per hectare using a vertical, multiple-fan sprayer.

\begin{tabular}{|c|c|c|c|c|c|}
\hline & \multirow{3}{*}{$\begin{array}{l}\text { Spray card } \\
\text { coverage (\%) } \\
\text { Immokalee } \\
2008\end{array}$} & \multicolumn{4}{|c|}{ Fruit detachment force $(\mathrm{N})$} \\
\hline & & \multicolumn{3}{|c|}{ Valencia } & \multirow{2}{*}{$\begin{array}{c}\text { Hamlin } \\
\text { Immokalee } \\
2006\end{array}$} \\
\hline & & $\begin{array}{c}\text { Immokalee } \\
2006\end{array}$ & $\begin{array}{c}\text { Immokalee } \\
2008\end{array}$ & $\begin{array}{c}\text { Lake Wales } \\
2008\end{array}$ & \\
\hline \multicolumn{6}{|l|}{$\overline{\text { Significance }^{z}}$} \\
\hline Height $\times$ depth & 0.7800 & 0.1391 & 0.2019 & 0.1863 & 0.5056 \\
\hline Depth & 0.0030 & $<0.0001$ & 0.2780 & $<0.0001$ & 0.0037 \\
\hline Height & $<0.0001$ & 0.0012 & 0.1725 & 0.6996 & 0.0751 \\
\hline Spray volume $\times$ block & 0.7800 & 0.0775 & 0.0136 & 0.0119 & 0.0016 \\
\hline Block & 0.0150 & 0.0004 & $<0.0001$ & 0.0820 & 0.0003 \\
\hline Spray volume & $<0.0001$ & 0.0002 & 0.0002 & $<0.0001$ & $<0.0001$ \\
\hline
\end{tabular}

Main effect means

Spray volume $\left(\mathrm{L} \cdot \mathrm{ha}^{-1}\right)^{\mathrm{y}}$

$\begin{array}{rr}0 & 6 \\ 935 & 33 \\ 1871 & 32 \\ 2806 & 58\end{array}$

$6 \mathrm{c}$
$33 \mathrm{~b}$
$32 \mathrm{~b}$
$58 \mathrm{a}$

$120 \mathrm{a}$
$54 \mathrm{c}$
$68 \mathrm{~b}$
$41 \mathrm{~d}$

$73 \mathrm{a}$
$57 \mathrm{~b}$
$45 \mathrm{c}$
$28 \mathrm{~d}$

$119 \mathrm{a}$
$75 \mathrm{~b}$
$66 \mathrm{c}$
$56 \mathrm{~d}$

94 a $-^{x}$ Height (m)

1
2
4

$20 \mathrm{~b}$
$28 \mathrm{~b}$
$51 \mathrm{a}$

\section{$66 \mathrm{~b}$} $61 \mathrm{~b}$ $77 \mathrm{a}$

53
51
50

79
80
78

$36 \mathrm{~b}$

Depth

\begin{tabular}{llllll} 
Inside & $25 \mathrm{~b}$ & $76 \mathrm{a}$ & 52 & $84 \mathrm{a}$ & $56 \mathrm{a}$ \\
Outside & $40 \mathrm{a}$ & $61 \mathrm{~b}$ & 50 & $74 \mathrm{~b}$ & $52 \mathrm{~b}$ \\
\hline
\end{tabular}

${ }^{2}$ The values presented are the $\mathrm{P}>\mathrm{F}$.

${ }^{y}$ Means within column with different letters were separated using Duncan's multiple range test for three or more means or analysis of variance for two means. Means without letters indicate no significant difference. ${ }^{\mathrm{x}}$ Treatment was not used in this trial. 
hectare of CMNP will result in a linear response in coverage and fruit loosening.

Yield components by mechanical harvesters. The ultimate goal of CMNP as an aid to mechanical harvesting is to maximize fruit recovery (fruit removed from the tree by the harvester minus fruit missed by the catch frame) while minimizing preharvest fruit drop. The percent preharvest fruit drop was generally higher with increasing volume of CMNP applied for each trial (Table 2). For all 'Valencia' trials, however, only the highest volume applied was significantly different from the control. There was a significant effect for all spray volumes applied in the 'Hamlin' trial. In general, we consider fruit drop above $2 \%$ unacceptable for harvester systems with catch frames. The $1871-\mathrm{L} \cdot \mathrm{ha}^{-1}$ rate was acceptable for all trials except the 'Hamlin' 2006 trial in which drop was 6.2\%, whereas the $2806-\mathrm{L} \cdot \mathrm{ha}^{-1}$ rate was unacceptable for two of the four trials.

Where different, the percent fruit removal generally increased when CMNP was applied at higher water volumes, except the 'Hamlin' trial conducted in 2006. The highest removal rate was increased by $16.9 \%$ when CMNP was applied at the two highest application volumes in Lake Wales 2008.

Catch frame loss, where different, was higher when CMNP was applied with higher water rates. The principle cause of fruit loss from catch frames was observed to be the result of impact of fruit by shields in front of the canopy shakers, which are designed to protect the equipment from branches. As a result of the heterogeneity of the canopy structure, especially with branches leaning into the tractor row from heavy crop load, the shields impacted the branches causing fruit to drop before the catch frame moved under the branch. We observed that higher spray volumes caused less fruit swinging and therefore easier detachment by the canopy shaker tines. This effect would be expected to improve fruit recovery by the machines because less fruit would be flung away from the catch frame. Maximum fruit recovery by mechanical harvesters will be aided by canopy architecture that promotes a uniform, relatively vertical canopy along the tractor row. Fruit recovery may also benefit by adjusting tractor and harvester designs with shields more offset to the center of the row and the canopy shakers and catch frames more exposed to the canopy.

Despite higher catch frame loss with CMNP application, the percent recovery was higher with higher spray volumes in two of the three trials in which machines with catch frames were used. These results indicate that CMNP application improves recovery when machines have catch frames. It would be expected that improvements in machine design and grove architecture to minimize catch frame loss may improve recovery.

The ultimate goal of using CMNP to aid mechanical harvesting is to remove sufficient fruit so that hand labor is not needed to remove fruit remaining in the tree. Where
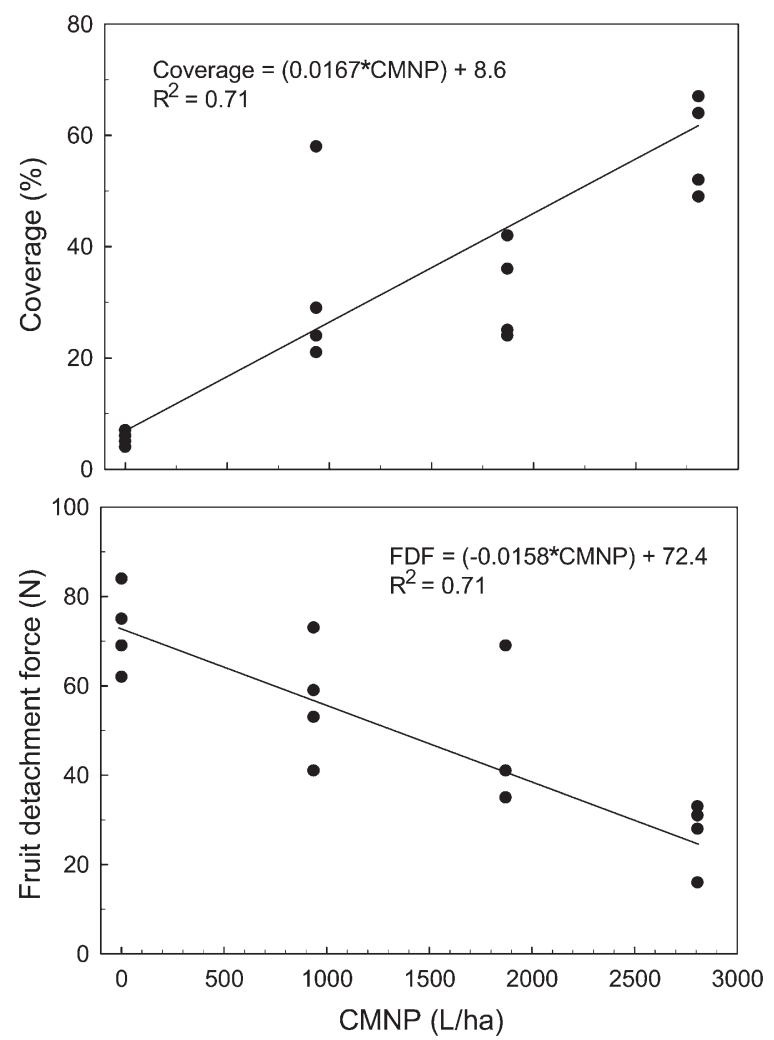

Fig. 2. Regressions for volume of CMNP applied per hectare on average coverage as measured by watersensitive paper and fruit detachment force throughout the canopy of 'Valencia' from the Immokalee 2008 trial. Both regressions were significant at the $P<0.0001$ level. Each data point is the mean for each block within each treatment.

Table 2. Yield components across spray volumes for one 'Hamlin' trial and three 'Valencia' trials.

\begin{tabular}{|c|c|c|c|c|c|}
\hline \multirow[b]{2}{*}{$\begin{array}{l}\text { CMNP applied } \\
\left(\mathrm{L} \cdot \mathrm{ha}^{-1}\right)\end{array}$} & \multicolumn{5}{|c|}{ Yield components ${ }^{\mathrm{yx}}$} \\
\hline & $\begin{array}{c}\text { Preharvest drop } \\
(\%)\end{array}$ & $\begin{array}{c}\text { Removal } \\
(\%)\end{array}$ & $\begin{array}{c}\text { Catch frame loss } \\
(\%)\end{array}$ & $\begin{array}{c}\text { Recovery } \\
(\%)\end{array}$ & $\begin{array}{c}\text { Glean } \\
(\%)\end{array}$ \\
\hline & \multicolumn{5}{|c|}{$\begin{array}{c}\text { Hamlin } \\
\text { Immokalee } 2006\end{array}$} \\
\hline 0 & $1.8 \mathrm{c}$ & 84.7 & $4.6 \mathrm{~b}$ & 80.1 & $13.4 \mathrm{a}$ \\
\hline 1871 & $6.2 \mathrm{~b}$ & 88.9 & $8.2 \mathrm{a}$ & 80.7 & $4.8 \mathrm{~b}$ \\
\hline \multirow[t]{2}{*}{2806} & $8.0 \mathrm{a}$ & 88.4 & $8.3 \mathrm{a}$ & 80.0 & $3.6 \mathrm{~b}$ \\
\hline & \multicolumn{5}{|c|}{$\begin{array}{c}\text { Valencia } \\
\text { Immokalee } 2006\end{array}$} \\
\hline 0 & $0.8 \mathrm{~b}$ & $87.4 \mathrm{~b}$ & 5.8 & $81.6 \mathrm{~b}$ & $12.3 \mathrm{a}$ \\
\hline 935 & $1.3 \mathrm{~b}$ & $92.9 \mathrm{a}$ & 7.0 & $85.8 \mathrm{a}$ & $6.1 \mathrm{~b}$ \\
\hline 1871 & $1.6 \mathrm{ab}$ & $94.2 \mathrm{a}$ & 7.2 & $87.0 \mathrm{a}$ & $4.7 \mathrm{~b}$ \\
\hline \multirow[t]{2}{*}{2806} & $2.3 \mathrm{a}$ & $94.9 \mathrm{a}$ & 7.1 & $87.8 \mathrm{a}$ & $3.3 \mathrm{~b}$ \\
\hline & \multicolumn{5}{|c|}{ Immokalee 2008} \\
\hline 0 & $1.0 \mathrm{~b}$ & $81.3 \mathrm{~b}$ & $3.1 \mathrm{~b}$ & $78.1 \mathrm{~b}$ & $16.1 \mathrm{a}$ \\
\hline 935 & $1.0 \mathrm{~b}$ & $83.5 \mathrm{~b}$ & $2.9 \mathrm{~b}$ & $80.7 \mathrm{~b}$ & $14.0 \mathrm{a}$ \\
\hline 1871 & $2.1 \mathrm{ab}$ & $89.5 \mathrm{a}$ & $2.8 \mathrm{~b}$ & $86.7 \mathrm{a}$ & $8.0 \mathrm{~b}$ \\
\hline \multirow[t]{2}{*}{2806} & $7.3 \mathrm{a}$ & $88.0 \mathrm{a}$ & $6.6 \mathrm{a}$ & $81.4 \mathrm{ab}$ & $5.7 \mathrm{~b}$ \\
\hline & \multicolumn{5}{|c|}{ Lake Wales 2008} \\
\hline 0 & $1.2 \mathrm{~b}$ & $70.6 \mathrm{~b}$ & $-^{\mathrm{w}}$ & - & $28.2 \mathrm{a}$ \\
\hline 935 & $1.1 \mathrm{~b}$ & $82.5 \mathrm{a}$ & - & - & $16.3 \mathrm{~b}$ \\
\hline 1871 & $1.7 \mathrm{ab}$ & $87.2 \mathrm{a}$ & - & - & $11.1 \mathrm{~b}$ \\
\hline 2806 & $2.4 \mathrm{a}$ & $87.5 \mathrm{a}$ & - & - & $10.1 \mathrm{~b}$ \\
\hline
\end{tabular}

${ }^{2}$ Yield component means are the percent of the total yield.

${ }^{\mathrm{y}}$ Preharvest drop = fruit under the canopy before mechanical harvesting; Removal = fruit removed by the mechanical harvester; Catch frame loss = fruit not captured by the catch frame during mechanical harvesting; Recovery = fruit caught by the catch frame; Glean = fruit left in tree after mechanical harvesting and removed by hand labor.

${ }^{x}$ Means within columns not followed by the same letter are significantly different at the $P<0.5$ level using Duncan's multiple range procedure. Means without letters indicate no significant difference.

wNot measured; no catch frame used by the harvester in this trial. 
different, the percent fruit that had to be gleaned decreased with increased spray volume. A goal of less than $5 \%$ of fruit left on the tree should be considered for maximizing mechanical harvesting with CMNP (F. Roka, unpublished data). Varying canopy shaker rates and tractor speed may improve removal and reduce the need for gleaning.

Optimizing CMNP application. More work is needed to understand the relationship between removal and CMNP application at different spray volumes, concentrations, and environmental conditions. In cases in which catch frames are used, minimizing preharvest fruit drop is critically important, because if a significant amount of the crop drops before harvest, ground fruit would have to be collected by hand before machine harvest could begin. For harvesters without catch frames, CMNP could be used at rates that optimize fruit removal because fruit drop and catch frame loss are not important factors to consider. However, the ultimate goal of use of CMNP for mechanical harvesters with catch frames is to maximize recovery, which is accomplished by minimizing fruit drop, promoting fruit removal, and minimizing catch frame loss such that gleaning is not required. Development of commercial recommendations for CMNP for canopy shakers with catch frames will require matching rates of CMNP applied, including concentration and volume applied per hectare, to an array of canopy shaker settings, including shaker head speed $(\mathrm{Hz})$ and tractor speed $\left(\mathrm{km} \cdot \mathrm{h}^{-1}\right)$, that control the energy the machines apply to the canopies.

Matching CMNP applications to mechanical harvester settings would be facilitated by finding a range of FDF values that allow maximum recovery by mechanical harvesters. Based on maximum recovery rates and minimizing preharvest fruit drop in these studies, target CMNP-promoted fruit loosening may be 40 to $65 \mathrm{~N}$.

\section{Literature Cited}

Alferez, F., S. Shila, A.L. Umback, B. Hockema, and J.K. Burns. 2005. Citrus abscission and Arabidopsis plant decline in response to 5chloro-3-methyl-4-nitro-1 $\mathrm{H}$-pyrazole are mediated by lipid signaling. Plant Cell Environ. 28:1436-1449.

Anonymous. 2008. Citrus summary, 2006-2007. Florida Agricultural Statistics Service, Fla. Dept. Agric. Consumer Services, Tallahassee, FL.

BenSalem, E., M. Sayani, and J.D. Whitney. 2001. Spray variable effects on deposition and harvesting efficacy of CMN-Pyrazole. Proc. Fla. State Hort. Soc. 114:111-118.

Burns, J.K., R.S. Buker III, and F.M. Roka. 2005. Mechanical harvesting capacity in sweet orange is increased with an abscission agent. HortTechnology 15:758-765.

Burns, J.K., L. Pozo, K. Morgan, and F. Roka. 2006. Better spray coverage can improve efficacy of abscission sprays for mechanically harvested oranges. Proc. Fla. State Hort. Soc. 119:190-194.

Ebel, R.C. and J.K. Burns. 2008. Incorporation of air temperature into a model that predicts loosening of sweet oranges by CMNP. Fla. State Hort. Soc. Proc. 121:160-163.

Farooq, M., M. Saylani, and J.D. Whitney. 2003. Effect of application techniques on abscission chemical deposition and mechanical harvesting of 'Valencia' oranges. HortTechnology 13: 344-350.

Florida Department of Citrus. 2008. Nov. 152008. $<$ http://citrusmh.ifas.ufl.edu/index.asp?s=2\&p=2>.

Freeman, B. and R.A. Sarooshi. 1976. Abscission chemicals for Valencia oranges in New South Wales. Aust. J. Exp. Agr. Anim. Husb. 16:943949.

Kender, W.J. and U. Hartmond. 1999. Variability in detachment force and other properties of fruit within orange tree canopies. Fruit Var. J. 53:105-109.

Koo, Y.M., M. Salyani, and J.D. Whitney. 1999. Effects of abscission chemical spray deposition on mechanical harvest efficacy of 'Hamlin' orange. Proc. Fla. State Hort. Soc. 112:28-33.

Koo, Y.M., M. Salyani, and J.D. Whitney. 2000 Spray variable effects on abscission of orange fruit for mechanical harvesting. Trans. Amer. Soc. Agric. Eng. 43:1067-1073.

McGuire, R.G. 1992. Reporting of objective color measurements. HortScience 27:12541255.

Pozo, L., R. Yuan, I. Kostenyuk, F. Alferez, G.Y. Zhong, and J.K. Burns. 2004. Differential effects of 1-methylcycopropene on citrus leaf and mature fruit abscission. J. Amer. Soc. Hort. Sci. 129:473-478.

Salyani, M., E. BenSalem, and J.D. Whitney. 2002. Spray deposition and abscission efficacy of CMN-pyrazole in mechanical harvesting of Valencia orange. Trans. Amer. Soc. Agr. Eng. 45:265-271.

Voss, D.H. and T.R. Robinson. 1992. Relating colorimeter measurement of plant color to the Royal Horticultural Society Colour Chart. HortScience 27:1256-1260.

Whitney, J.D. 1975. Orange yield and removal studies with air and trunk shakers using two abscission chemicals. Proc. Fla. State Hort. Soc. 88:120-124.

Whitney, J.D. 1976. Air shaker harvest trials in 'Valencia' oranges with two rates of abscission chemical. Proc. Fla. State Hort. Soc. $89: 41-43$

Whitney, J.D. 2000. Performance of mechanical citrus harvesters in Florida. Proc. Intl. Soc. Citricul. IX Congr. p. 277-279.

Whitney, J.D. 2003. Trunk shaker and abscission chemical effects on yields, fruit removal, and growth of orange trees. Proc. Fla. State Hort. Soc. 116:230-235.

Whitney, J.D., E. BenSalem, and M. Salyani. 2001. The effect of trunk shaker patterns on Florida orange removal. Appl. Eng. Agr. 17:461464.

Whitney, J.D., U. Hartmond, W.J. Kender, J.K Burns, and M. Salyani. 2000a. Orange removal with trunk shakers and abscission chemicals. App. Eng Agr. 16:367-371.

Whitney, J.D., U. Hartmond, W.J. Kender, M. Salyani, and J.K. Burns. 2000b. Abscission chemicals affect trunk shaker orange removal. Proc. Fla. State Hort. Soc. 113:93-96.

Wilson, W.C. 1973. A comparison of cycloheximide with a new abscission chemical. Florida State Hort. Soc. 86:56-60. 